\title{
PARAMETER POPULASI DAN POLA REKRUITMEN IKAN TONGKOL LISONG (Auxis rochei Risso, 1810) DI PERAIRAN BARAT SUMATERA
}

\section{PARAMETERS AND RECRUITMENT PATTERN OF BULLET TUNA (Auxis rochei Risso, 1810) IN WEST COASTS SUMATERA}

\author{
Tegoeh Noegroho dan Umi Chodrijah \\ Balai Penelitian Perikanan Laut \\ Teregistrasi I tanggal: 03 April 2014; Diterima setelah perbaikan tanggal: 02 Desember 2015; \\ Disetujui terbit tanggal: 04 Desember 2015 \\ e-mail: tegoeh_brtehnik@yahoo.com
}

\begin{abstract}
ABSTRAK
Perikanan neritik tuna di perairan Barat Sumatera berkembang pesat beberapa dekade terakhir ini. Sementara belum banyak diperoleh hasil penelitian tentang populasi ikan tongkol lisong (Auxis rochei). Penelitian tentang parameter populasi dan pola rekruitmen ikan tongkol lisong dilakukan pada bulan Februari-Desember 2013 di beberapa lokasi pendaratan ikan di Barat Sumatera. Tujuan penelitian ini adalah untuk memperoleh laju pertumbuhan, panjang asimptotik, laju kematian, laju eksploitasi, dan pola rekruitmen ikan tongkol lisong (Auxis rochei). Estimasi parameter populasi menggunakan model analitik berdasarkan program "Electronic Length Frequency Analysis (ELEFAN 1)". Data frekuensi panjang dikumpulkan berkesinambungan di beberapa tempat pendaratan utama. Hasil penelitian menunjukkan panjang cagak ikan tongkol lisong yang tertangkap berada pada kisaran 11-42 cm FL. Parameter pertumbuhan Von Bertalanffy diperoleh nilai laju pertumbuhan (K) sebesar 0,54/tahun, panjang asimptotik (L) sebesar 43,5 cm FL, dan umur ikan pada saat panjang ke-0 (- $\left.\mathrm{t}_{0}\right)$ sebesar -0,076/tahun. Laju mortalitas total (Z) sebesar 1,96/tahun. Laju kematian karena penangkapan (F) sebesar 1,07/tahun, dan laju kematian alami (M) 0,89/tahun. Laju eksploitasi (E) tongkol lisong di Barat Sumatera adalah 0,49/tahun atau berada pada tingkat eksploitasi moderat. Pola rekrutmen tongkol lisong terjadi dua kali dalam setahunnya, yaitu mencapai puncak pada bulan Maret dan Juni.
\end{abstract}

KATA KUNCI: Auxis rochei, parameter populasi, Barat Sumatera

\section{ABSTRACT}

Neritic tuna fishery in the West Sumatra waters was developed very intensively in the captured. Meanwhile, study population of bullet tuna (Auxis rochei) in those are still limited. Research in population parameters and recruitmen pattern of bullet tuna has been conducted in February-December 2013 based on several landing place in West Sumatra. The aim of this study is to obtain asymptotic length, mortality rate, exploitation rate, and recruitment pattern of bullet tuna (Auxis rochei). Estimation of population parameters using an analytical model based on the program "Electronic Length Frequency Analysis (ELEFAN 1)". Length frequency data collected continuously in the main landing places The results showed the fork length of bullet tuna was caught in the range $11-42 \mathrm{~cm} F L$. Von Bertalanffy growth parameters obtained the growth rate value $(K)$ of 0,54/year, asymptotic length $\left(L^{\infty}\right)$ of $43,5 \mathrm{~cm} F L$, and fish age when the length to the- $0\left(-t_{0}\right)$ of $-0,076 /$ year. Total mortality was 1,96/ year. Fishing mortality rate $(F)$ was 1,07/year and natural mortality rate $(M) 0,89 /$ year. The exploitation rate $(E)$ of bullet tiuna in West Sumatra was 0,49/year or are at a moderate level of exploitation. Recruitment patterns of bullet tuna happen twice in a year, which reached a peak in March and June.

\section{KEYWORDS: Auxis rochei, population parameter, West Sumatera}

\section{PENDAHULUAN}

Ikan tongkol dan tenggiri dapat dimasukkan sebagai kelompok ikan tuna neritik. Tuna neritik adalah kelompok ikan tuna yang habitat hidupnya di perairan neritik atau perairan dangkal dengan kedalaman kurang dari 200 meter. Termasuk kelompok ini antara lain tongkol abu-abu atau longtail tuna (Thunnus tonggol), tongkol komo/kawakawa atau eastern little tuna (Euthynnus affinis), tongkol krai atau frigate tuna (Auxis thazard), lisong atau bullet Korespondensi penulis:

Balai Penelitian Perikanan Laut-Muara Baru, Jakarta

Jl. Muara Baru Ujung, Komp. PPS Nizam Zachman-Jakarta Utara tuna (Auxis rochei), tenggiri atau narrow-barred spanish mackerel (Scomberomorus commerson) dan tenggiri papan atau indo-pasific king mackerel (Scomberomorus guttatus) (Herrera \& Pierre, 2009).

Tongkol lisong (Auxis rochei Risso 1810) termasuk famili Scombridae genus Auxis, mempunyai penyebaran luas di perairan tropis dan subtropis. Auxis rochei adalah spesies yang mempunyai habitat di daerah epipelagik atau mesopelagik dan penyebarannya dipengaruhi oleh 
perubahan suhu perairan pantai (Uchida, 1981; Collete, 1986). Tongkol lisong di perairan Barat Sumatera pengusahaannya dilakukan oleh nelayan dengan menggunakan alat tangkap purse seine, pancing tonda, bagan perahu, dan payang. Ada beberapa daerah yang menjadi basis pendaratan tongkol lisong, antara lain: Banda Aceh, Meulaboh, Sibolga, Padang, Bengkulu dan Lampung.

Produksi ikan tongkol lisong di WPP 572 telah tercatat pada statistik perikanan tangkap mulai tahun 2005. Pada tahun sebelumnya produksi seluruh jenis ikan tongkol tercatat di data statistik dalam jenis tongkol saja, tanpa membedakan spesiesnya. Produksi ikan tongkol lisong dari tahun 2005-2012 menunjukkan tren yang berfluktuasi, terendah pada tahun 2005-2007 dan naik pesat pada 20082012. Ikan tongkol lisong hanya berkontribusi $2 \%$ dari seluruh produksi tuna neritik yang berasal dari perairan Barat Sumatera (Anonymous, 2013). Nilai ini sangat kecil dibanding persentase jenis tongkol yang lainnya seperti tongkol krai sebesar $26 \%$, ada kemungkinan petugas pencatatan data di lapangan salah mengidentifikasi karena secara morfologi ikan tongkol lisong dan tongkol krai sangat mirip. Neritik tuna hasil tangkapan nelayan selain dipasarkan di pasar lokal juga ada beberapa yang masuk industri dan diekspor. Tingkat pengusahaan tongkol lisong yang terus-menerus tanpa adanya kontrol dapat menyebabkan kelestariannya terancam, oleh sebab itu informasi ilmiah yang akurat dan tepat sangat dibutuhkan.

Penelitian tentang parameter populasi ikan tongkol lisong masih terbatas dilakukan di Indonesia khususnya di perairan Samudera Hindia Barat Sumatera. Penelitian awal tentang biologi ikan tongkol lisong telah dilakukan oleh Widodo et al. (2011), Setyadji et al. (2013) dan Noegroho et al. (2013) di Samudera Hindia Selatan Jawa dan Barat Sumatera. Beberapa parameter populasi dalam dinamika populasi sangat penting untuk diketahui pada perikanan yang sedang dieksploitasi di suatu perairan.Tujuan dari penelitian ini adalah untuk mengetahui beberapa parameter populasi meliputi laju pertumbuhan, laju kematian, laju eksploitasi dan pola rekruitmen ikan tongkol lisong. Hasil penelitian ini diharapkan dapat diketahui status pemanfaatan ikan tongkol lisong pada saat ini dan dapat dijadikan sebagai bahan pertimbangan dalam pengelolaan sumberdaya ikan tongkol lisong yang berkelanjutan.

\section{BAHANDANMETODE \\ Waktu dan Lokasi Penelitian}

Penelitian dilakukan pada Februari sampai Desember 2013. Pengumpulan data bulanan di lakukan di beberapa tempat pendaratan ikan di Barat Sumatera yaitu Banda Aceh, Meulaboh dan Padang. Selama penelitian diperoleh sampel frekuensi panjang ikan tongkol lisong sebanyak 4327 ekor. Tongkol lisong yang didaratkan berasal dari hasil tangkapan nelayan menggunakan purse seine, gillnet, pancing tonda dan payang di perairan Barat Sumatera. Lokasi yang dijadikan sebagai tempat sampling ditunjukkan pada Gambar 1.

Alat yang digunakan dalam penelitian antara lain alat ukur untuk mengukur panjang ikan dengan ketelitian 0,1 $\mathrm{cm}$, buku dan alat tulis.

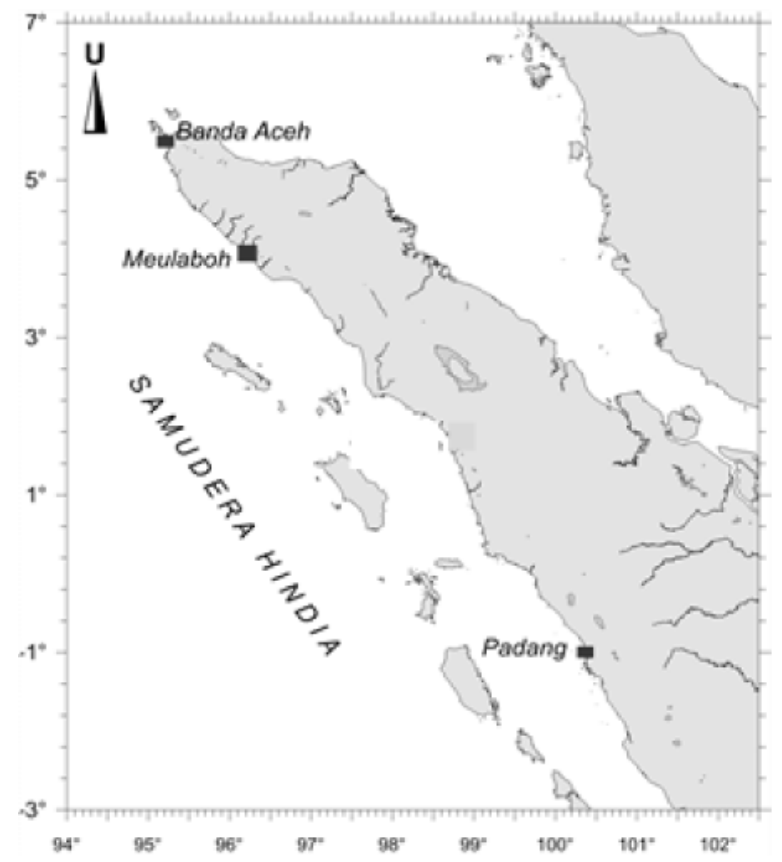

Gambar 1. Peta lokasi peneliti di pantai Barat Sumatera .

Figure 1. Map showing location of sampling site in west coasts of Sumatera. 


\section{Frekuensi Panjang Tongkol Lisong}

Sampling ikan diambil secara acak di tempat pendaratan ikan maupun di pengumpul ikan. Panjang ikan yang diukur adalah fork length, yaitu panjang yang diukur dari ujung mulut sampai titik tengah cagak ekor. Panjang diukur menggunakan meteran dengan satuan centimeter. Dari hasil ukuran panjang ikan kemudian dibuat persentase frekuensi panjang pada interval kelas $2 \mathrm{~cm}$ untuk ikan tongkol lisong (Auxis rochei).

Parameter pertumbuhan ( $\mathrm{K}$ dan $\mathrm{L} \infty$ ) diestimasi melalui aplikasi dengan metode Electronic Length Frequency Analysis (ELEFAN-1) di komputer dalam software FISAT (Gayanilo et al., 1996). Berdasarkan persamaan Von Bertalanffy dan Beverton \& Holt (1956) sebagai berikut:

$\mathrm{Lt}=\mathrm{L} \infty\left(1-\mathrm{e}_{0}^{-\mathrm{K}(\mathrm{t}-\mathrm{t})}\right)$

dimana:

$\mathrm{Lt}=$ panjang pada umur $\mathrm{t}$

L $\infty=$ panjang asimtotik (infinity)

$\mathrm{K}=$ parameter yang menggambarkan kecepatan mencapai $\mathrm{L}^{\infty}$

$\mathrm{t}_{0}=$ umur teoritis saat ikan berukuran panjang nol

Parameter $\mathrm{t}_{\mathrm{o}}$ (umur pada saat 0 tahun) dihitung berdasarkan persamaan Pauly (1984) yaitu:

$\log \left(-t_{0}\right)=0,3922-0,2752 \log (\operatorname{L} \infty)-1,038 \log (K)$

Laju mortalitas alami (M) diduga dengan mengaplikasikan model empiris dari Pauly (1980) yaitu:

$\log (M)=-0,0066-0,279 \times \log \left(L^{\infty}\right)+0,6543 \times \log$ $(\mathrm{K})+0,4634 \mathrm{x} \log (\mathrm{T})$.

Koefisien mortalitas total (Z) diperoleh dari kurva hasil tangkapan berdasarkan panjang (length converted catch curve) (Pauly, 1983), perhitungannya dilakukan secara komputerisasi menggunakan paket program FISAT (Gayanilo et al., 1996). Laju mortalitas penangkapan (F) diestimasi dengan menggunakan persamaan :

$\mathrm{F}=\mathrm{Z}-\mathrm{M}$

Laju eksploitasi (E) dihitung menggunakan persamaan Pauly (1983), yaitu:

$\mathrm{E}=\mathrm{F} / \mathrm{Z}=\mathrm{F} /(\mathrm{F}+\mathrm{M})$

dimana:

$\mathrm{M}=$ laju mortalitas

$\mathrm{T}=$ rata-rata suhu perairan (30ÚC)

$\mathrm{E}=$ tingkat eksploitasi

$\mathrm{Z}=$ mortalitas total
$\mathrm{F}=$ mortalitas penangkapan

Pendugaan pola rekrutmen menggunakan program FISAT dengan input data $\mathrm{L} \infty, \mathrm{K}$, dan $\mathrm{t}_{\mathrm{o}}$ (Gayanilo et al., 1996). Pola rekruitmen bertujuan untuk melihat terjadinya penambahan baru (recruitmen) spesies tertentu dalam setahun dengan berdasarkan runut waktu dari sebaran frekuensi panjang ikan.

\section{HASIL DAN BAHASAN \\ Hasil}

\section{Sebaran Frekuensi Panjang}

Pengukuran panjang cagak dilakukan terhadap 4327 ekor ikan tongkol lisong. Ukuran panjang cagak berkisar antara 11-42 cm FL. Sebaran panang cagak setiap bulan diperlihatkan pada Gambar 2. Ada beberapa bulan yang mempunyai modus sama yaitu pada Februari, April, Juni, Juli, dan Oktober dengan nilai 25-26 cm FL (25,5 cm ML), nilai modus $21-22 \mathrm{~cm}$ FL (21,5 cm ML) ditemukan pada Maret dan September, nilai modus 27-28 cm FL (27,5 cm ML) ditemukan pada Agustus, November, dan Desember, sedangkan nilai modus pada ukuran ikan yang lebih panjang ditemukan pada Juli yaitu $37-38 \mathrm{~cm}$ FL (37,5 cm ML). Distribusi frekuensi panjang dari bulan FebruariDesember mempunyai nilai modus pada kisaran $25-26 \mathrm{~cm}$ FL. Modus ukuran panjang ikan tidak menunjukkan pergeseran yang signifikan setiap bulannya. Terlihat pada Gambar 2 beberapa nilai modus yang sama setiap bulannya.

\section{Laju Pertumbuhan dan Umur}

Dengan menurut data frekuensi panjang cagak ikan tongkol lisong dari Februari-Desember menggunakan perangkat lunak ELEFAN I (lihat Gambar 3) diperoleh panjang asimptotik (L $\infty)$ sebesar 43,5 $\mathrm{cm}$ FL, dan laju pertumbuhan $(\mathrm{K})$ sebesar 0,54 per tahun serta umur ikan pada saat panjang ikan nol $\left(\mathrm{t}_{0}\right)$ sebesar $-0,076 /$ tahun.

Dengan demikian persamaan pertumbuhan Von Bertalanffy sebagai $\mathrm{Lt}=43,5\left(1-\mathrm{e}^{-0,54(\mathrm{t}+0,076)}\right)$. Dari persamaan tersebut dapat dibuat kurva hubungan antara umur dengan panjang ikan sebagaimanan digambarkan pada Gambar 4.

\section{Laju Kematian}

Dari kurva hasil tangkapan berdasarkan panjang diperoleh laju mortalitas alami (M) menjadi 0,89 per tahun dan laju mortalitas karena penangkapan 1,07 per tahun (Gambar 5). Dengan demikian laju mortalitas total (Z) menjadi 1,96 per tahun. 

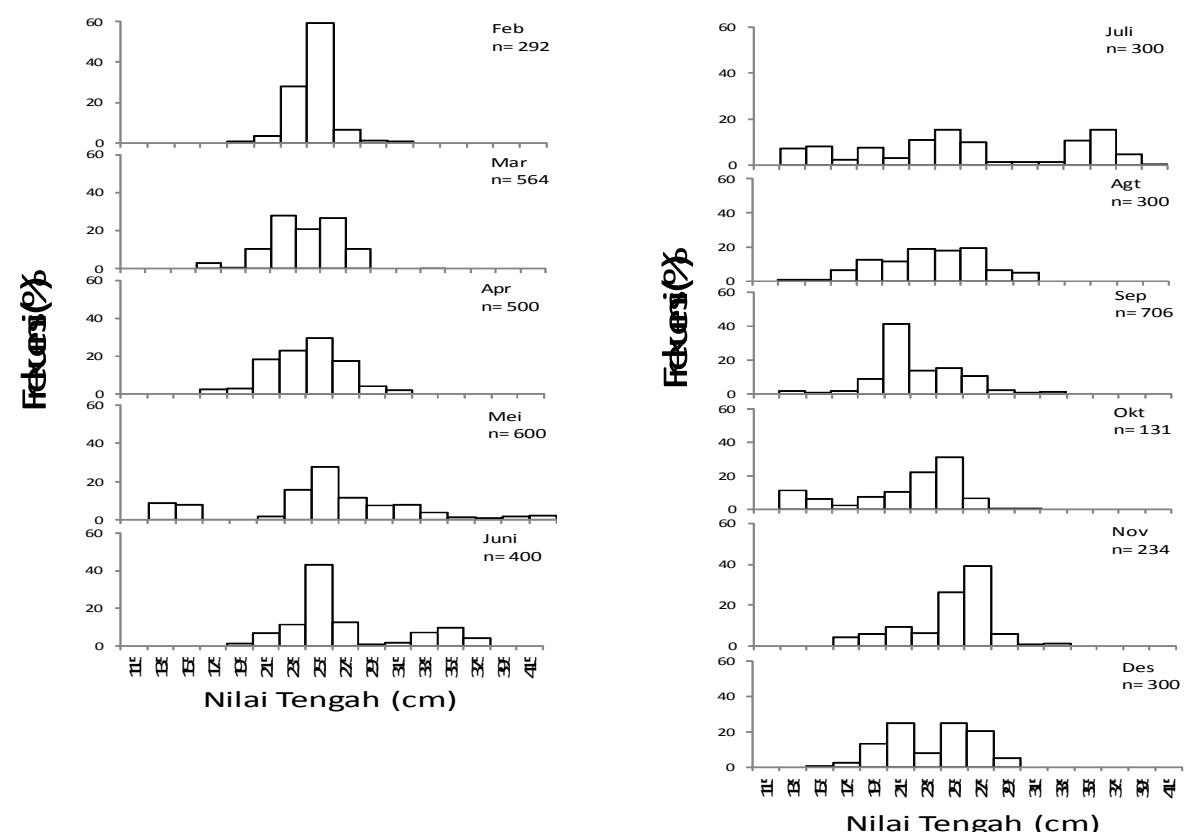

Gambar 2. Distribusi frekuensi panjang cagak ikan tongkol lisong di perairan Barat Sumatera bulan Februari-Desember 2013.

Figure 2. Length frequency distribution of bullet tuna at west coast Sumatera Februari-Desember 2013.



Gambar 3. Kurva pertumbuhan von bertalanffy ikan tongkol lisong (Auxis rochei).

Figure 3. Von bertalanffy growth curve of bullet tuna (Auxis rochei).

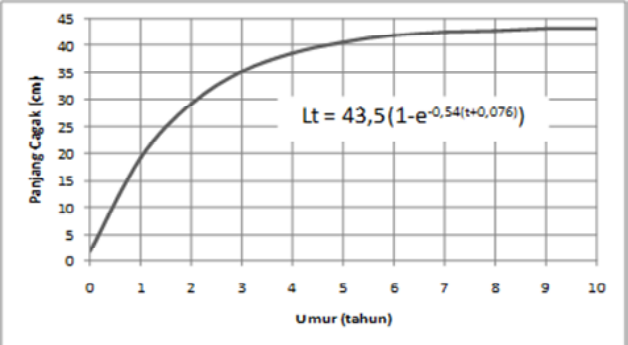

Gambar 4. Kurva pertumbuhan ikan tongkol lisong di perairan Barat Sumatera.

Figure 4. Growth curve of bullet tuna at West Sumatera water.

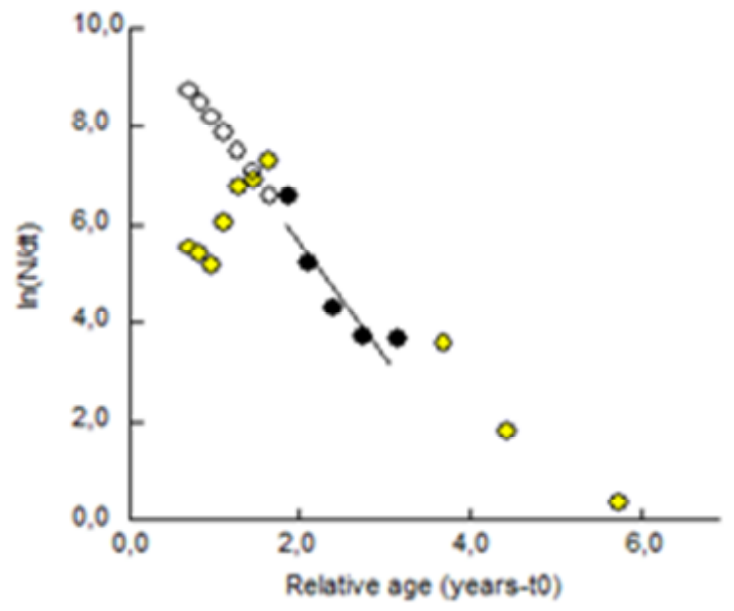

Gambar 5. Kurva hasil tangkapan berdasarkan ukuran panjang ikan tongkol lisong. Figure 5. Length converted catch curve of bullet tuna. 


\section{Tingkat Eksploitasi}

Tingkat eksploitasi di suatu perairan agar diperoleh hasil tangkapan yang lestari dan rasional nilai $\mathrm{E}<0,50$ (Pauly et al. 1984). Tingkat eksploitasi (E) ikan tongkol lisong di perairan Barat Sumatera adalah 0,49/tahun, bila dibandingkan dengan Eoptimal 0,50 berarti pemanfaatan sumberdaya ikan tongkol lisong di WPP 572 sudah hampir optimum.

\section{Pola Rekrutmen}

Hasil analisis menunjukkan rekrutmen ikan tongkol lisong terjadi dua kali dalam setahun dengan puncak tertinggi pada bulan Maret dan Juni (Gambar 6). Nilai rekrutmen relatif bulan Juni sedikit lebih besar dibandingkan dengan bulan Maret, yaitu $16,78 \%$ dibanding $16,76 \%$.

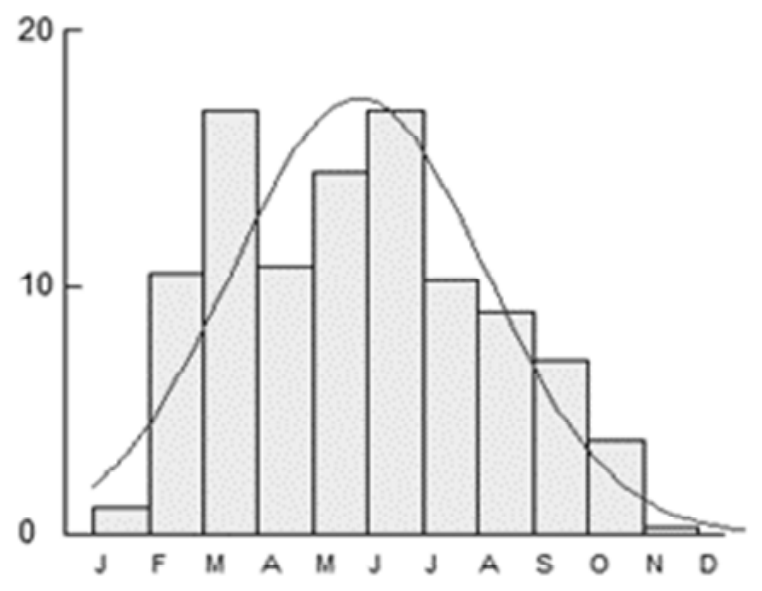

Gambar 6. Pola rekrutmen ikan tongkol lisong di perairan Barat Sumatera.

Figure 6. Recruitment pattern of bullet tuna at West Sumatera water.

\section{Bahasan}

Pergeseran modus ukuran ikan-ikan yang tertangkap di rumpon menunjukkan ukuran yang relatif sama setiap bulannya, hal ini diduga disebabkan daerah penangkapan yang berada di sekitar rumpon. Ikan-ikan yang berada di rumpon cenderung berada dalam gerombolan (schooling), sehingga ukuran yang tertangkap relatif seragam. Ikan-ikan tersebut tertarik dan berasosiasi dengan rumpon secara temporer. Ikan tongkol lisong mendiami suatu rumpon dapat berlangsung satu atau beberapa bulan dan kondisi ini berlangsung terus-menerus dalam sebuah rantai makanan yang terjadi di rumpon. Kisaran ukuran yang diperoleh di Barat Sumatera hampir sama dengan yang dilaporkan oleh Jasmine (2013) di perairan India seperti yang terlihat pada Tabel 1. Perbedaan kisaran ukuran yang tertangkap di beberapa lokasi disebabkan adanya perbedaan dalam penggunaan alat tangkap.

Tabel 1. Kisaran panjang ikan tongkol lisong di beberapa lokasi

Table 1. Size distribution of bullet tuna in several place

\begin{tabular}{|c|c|c|c|c|c|}
\hline Lokasi/Location & Alat Tangkap/Fising gear & K & $\begin{array}{l}\text { Kisaran/Range } \\
(\mathrm{cm})\end{array}$ & $\begin{array}{l}\text { Modus } \\
\text { (Cm) }\end{array}$ & Referensi/Reference \\
\hline Laut India & gillnet, purse seine, handline, tonda & & $15-30$ & & Pillai \& N.GK. Pillai, (2000) \\
\hline Perairan Turki & tuna purse seine & 630 & $28,5-44,5$ & 36,5 & Bok \& Oray (2001) \\
\hline Tenggara Laut Mediterania & & & $25-47$ & 36 & Macias et al. (2006) \\
\hline Laut Liguaria, Italia & & 83 & $27-46,5$ & & Plandri et al. (2009) \\
\hline Pantai Mediterania, Turki & purse seine, tonda & 216 & $34-48$ & $41-42$ & Kahraman et al. (2011) \\
\hline Perairan Cilacap & gillnet & 185 & $20-45$ & 40 & Widodo et al . (2011) \\
\hline Srilanka & gillnet & & $17-40$ & $27-30$ & Bandarayanake \& Maldeniya. (2012) \\
\hline Perairan India & gillnet, handline & & $10-40$. & $22-26$ & Jasmine et al . (2013) \\
\hline \multirow[t]{2}{*}{ Selatan Jawa, Samudera Hindia } & purse seine mini & 34 & $23-32$ & 30 & Setyadi et al . (2013) \\
\hline & purse seine besar & 41 & $20-28$ & $20-22$ & \\
\hline Barat Sumatera, Samudera Hindia & purse seine, payang, bagan perahu, tonda & 4327 & $11-42$. & $25-26$ & Penelitian ini \\
\hline
\end{tabular}

Panjang pertama kali matang gonad (Lm) ikan tongkol lisong adalah 24,6 cm (Balai Penelitian Perikanan Laut, 2013). Berdasarkan nilai Lm tersebut, distribusi panjang ikan tongkol lisong yang tertangkap di perairan Barat Sumatera menunjukkan ikan yang telah dewasa sebesar $53 \%$ dan yang belum dewasa $47 \%$. Setyadji et al. (2013) di Samudera Hindia Selatan Jawa dari alat tangkap purse seine memperoleh kisaran yang lebih berbeda yaitu 23-32 cm untuk purse seine mini dan 20-28 cm untuk purse seine besar (skala industri). Perbedaan ukuran panjang ikan yang tertangkap salahsatunya disebabkan oleh perbedaan besarnya mata jaring yang digunakan. Populasi ikan tongkol lisong akan lestari bila ukuran yang ditangkap diatas panjang pertama kali matang gonad. Eksploitasi 
terhadap juvenille ikan tongkol lisong secara terus menerus dengan alat tangkap purse seine yang tidak selektif akan menyebabkan kelestarian tongkol lisong terancam.

Dari kurva pertumbuhan dapat diketahui tongkol lisong pada umur 1, 2, dan 3 tahun masing-masing mempunyai panjang 1,7, 19,2, dan 29,3 cm. Panjang asimptotik (Lo) ikan tongkol lisong adalah 43,5 cm FL dan dicapai pada umur ikan $>9$ tahun. Ikan tongkol lisong yang tertangkap lebih banyak yang berumur $>1$ tahun atau berada pada kisaran 25-26 cm FL. Panjang asimptotik dan laju pertumbuhan tongkol lisong hasil penelitian ini dapat dibandingkan dengan penelitian yang telah ada pada Tabel 2 .

Tabel 2. Estimasi parameter pertumbuhan ikan tongkol lisong (Auxis rochei)

Table 2. Estimation growth parameter of bullet tuna (Auxis rochei)

\begin{tabular}{|c|c|c|c|c|}
\hline Lokasi/Location & $\mathrm{L} \infty(\mathrm{cm})$ & $\mathrm{K} /$ tahun & $t_{0}$ & Referensi/Reference \\
\hline$\overline{\text { Atlantik Timur }}$ & 41,5 & 0,32 & $-0,83$ & Grudtsev. (1992) \\
\hline Kerala, India & 37 & 0,6 & & James et al. (1993) \\
\hline Mediterania Timur & 47,7 & 0,92 & $-2,36$ & Bok \& Oray. (2001) \\
\hline Mediterania Barat & 73,2 & 0,44 & $-1,02$ & De La Serna et al. (2005) \\
\hline Mediterania Barat & 44 & 0,7 & $-0,14$ & Valeiras et al. (2008) \\
\hline Pantai Mediterania, Turki & 57,4 & 0,18 & $-4,15$ & Kahraman et al . (2011) \\
\hline Perairan India & 34 & 1,1 & & Gopakkumar \& Ajithkumar. (2002) dalam Rohit et al. (2011) \\
\hline Perairan India & 42,3 & 0,61 & $-0,03$ & Jasmine et al. (2013) \\
\hline Barat Sumatera, Samudera Hindia & 43,5 & 0,54 & $-0,076$ & Penelitian ini \\
\hline
\end{tabular}

Tongkol lisong di perairan Barat Sumatera mempunyai panjang asimptotik lebih besar $(43,5 \mathrm{~cm})$ dan laju pertumbuhan lebih cepat $(0,54 /$ tahun $)$ dibanding di perairan India. dengan Laju kematian ikan tongkol lisong karena penangkapan lebih tinggi dibandingkan dengan tingkat kematian alami. Laju kematian karenan penangkapan ikan tongkol lisong di Barat Sumatera hampir sama dengan yang dilaporkan James et al. (1993) di Kerala, India, dan lebih kecil dari yang dilaporkan oleh Gopakumar
\& Ajithkumar (2002) dalam Rohit et al. (2011) di perairan India juga. Nilai $F$ yang tinggi di perairan India memperlihatkan penangkapan tongkol lisong yang sangat intensif. Laju mortalitas dan laju eksploitasi ikan tongkol lisong di beberapa lokasi tersaji pada Tabel 3. Laju eksploitasi ikan tongkol lisong di perairan Barat Sumatera hampir penuh tereksploitasi $(E=0,49)$, namun masih memungkinkan untuk dimanfaatkan tentunya dalam pengawasan dan kehati-hatian.

Tabel 3. Estimasi nilai Z, M, F, dan E ikan tongkol lisong dari beberapa lokasi

Table 3. Estimation of $Z, M, F$, and E value of bullet tuna at several location

\begin{tabular}{lcccll}
\hline \multicolumn{1}{c}{ Lokasi/Location } & Z & M & F & E & Referensi/Reference \\
\hline Kerala, India & 1,97 & 1,20 & 1,77 & James et al. (1993) \\
Perairan India & 4,81 & 1,85 & 2,96 & Gopakkumar \& Ajithkumar. (2002) dalam Rohit et al. (2011) \\
Laut India (ZEE) & 1,87 & 1,21 & 0,66 & 0,35 Rohit et al. (2011) \\
Perairan India & 5,90 & 1,18 & 4,72 & 0,80 Jasmine et al. (2013) \\
Barat Sumatera, Samu dera Hindia & 1,96 & 0,89 & 1,07 & 0,49 Penelitian ini \\
\hline
\end{tabular}

Bila mortalitas total di alam sebelum ada penangkapan adalah 2,0 per tahun, maka nilai itu hanya berasal dari mortalitas alami. Kemudian ketika mulai ada aktifitas penangkapan, mortalitas karena penangkapan mulai terjadi dan mortalitas alami berkurang. Bila laju mortalitas penangkapan mencapai 1 per tahun berarti seluruh kohort telah penuh dieksploitasi atau telah tertangkap (Beverton \& Holt, 1957). Laju mortalitas penangkapan ikan tongkol lisong di perairan Barat Sumatera telah menunjukkan intensitas yang tinggi $(\mathrm{F}>1)$. Nilai $F$ harus diusahakan dan dikendalikan supaya $<1$. Nilai F dapat dikendalikan dengan pengaturan jumlah armada penangkapan, jumlah alat tangkap, besarnya mata jaring, daerah penangkapan dan ukuran kapal.
Pola rekrutmen tongkol lisong di perairan Barat Sumatera terjadi dua kali, rekruit yang lebih besar terjadi akhir musim peralihan pertama yaitu Maret, dan rekruit yang kedua terjadi pada awal musim timur yaitu Juni. Penentu besarnya rekrutmen adalah jumlah induk yang siap memijah dan mortalitas pada rentang waktu antara pemijahan dengan ikan mencapai ukuran stok. Keberhasilan rekrutmen juga ditentukan kondisi lingkungan saat datangnya kohort pascalarva pada nursery ground. Agar rekrutmen tongkol lisong diperairan lebih besar maka yang dapat dilakukan adalah mengatur kegiatan penangkapan supaya induk yang tersedia dan siap memijah lebih banyak jumlahnya. 


\section{KESIMPULAN}

Komposisi ikan tongkol lisong hasil tangkapan pukat cincin, tonda, gillnet, bagan dan payang di perairan Barat Sumatera pada bulan Februari-Desember 2013 terdiri dari ikan dewasa (panjang cagak > $24 \mathrm{~cm}$ FL) sebanyak 53\% dan belum dewasa (panjang cagak $<24 \mathrm{~cm} \mathrm{FL)} \mathrm{sebanyak}$ $47 \%$. Pertumbuhan ikan tongkol lisong di Samudera Hindia Barat Sumatera tergolong cepat dengan laju pertumbuhan (K) mencapai 0,54/tahun. Panjang asimptotik ikan tongkol lisong 43,5 cm tercapai pada umur $>9$ tahun. Perikanan tongkol lisong di Barat Sumatera hampir penuh tereksploitasi sehingga pemanfaatan harus mulai dibatasi karena penangkapannya cenderung semakin intensif $(\mathrm{F}>1)$. Pola rekrutmen tongkol lisong di perairan Barat Sumatera terjadi dua kali dalam setahun, dengan puncak pada bulan Maret dan Juni.

\section{DAFTAR PUSTAKA}

Balai Penelitian Perikanan Laut., 2013. Penelitian aspek biologi, tingkat pemanfaatan, dan optimasi pemanfaatan sumberdaya ikan pelagis besar di WPP 572, WPP 573, dan WPP 717 untuk mendukung industrialisasi perikanan. Laporan Akhir (Tidak di publikasi).

Bandaranayake, K.H.K. \& R. Maldeniya. 2012. A review on neritic tuna resources in Srilanka. IOTC Second Working Party on Neritic Tuna (09):1-12.

Beverton, R. J. H. \& S. J. Holt. 1956. A review of methods for estimating mortality rates in exploited fish populations, with special reference to sources of bias in catch sampling. Rapp. P-V. Reun. CIEM, 140: 67-83.

Beverton, R. J. H. \& S. J. Holt. 1957. On the dynamics of exploited fish populations. fishery investigations ministry of agriculture and food (Great Britain) series 2(19): $533 \mathrm{p}$.

Bok, T. \& Oray I. K.. 2001. Age and growth of bullet tuna auxis rochei (risso, 1810) in Turkish waters. ICCAT, Col. Vol. Sci. Pap., 52: 708-718.

Collete, B. B. 1986. Scombridae. In: P. J. P. White Head, M. L. Bauchot, J. C. Hureau, J. Nielsen, and E. Tortonese (Eds.), Fishes of the north-eastern Atlantic and the Mediterranea. Vol II: 981-997.

De la Serna, J. M., Ortiz de Urbina, J. M., Alot, E., Garcia, S. and Rioja, P. 2005. Biological parameters of bullet tuna (Auxis rochei) observed in the Spanish Mediterranean fisheries. Col. Vol. Sci. Pap. ICCAT, 58(2): 517-526.
Gayanilo, F. C. Jr., Sparre, P. \& Pauly, D. 1996. The FAO ICLARM stock assessment tools (FISAT) user's guide. FAO computerized information series (fisheries). Rome, FAO, 126 p.

Grudtsev, M. E. 1992. Particularites de repartition et caracteristique biologique de le melva Auxis rochei (Risso) dams les eaux du Sahara. ICCAT. Coll. Vol. Sci Pap., 39(1):351-377.

Herrera, M \& L. Pierre. 2009. Status of IOTC databases for neritic tuna. IOTC-WPDCS-06.1-46.

James, P. S. B. R., P. P. Pillai, N. G. K. Pillai, A. A. Jayaprakash, G. Gopakumar, H. Mohamad Kasim M. Sivadas \& K. P. Said Koya. 1993. Fishery, biology and stock assessment of small tunas. In: D. Sudarshan \& M. E. John (Eds) Tuna Research in India Report, Bombay:123-148.

Jasmine, S., Prathibha Rohit, E. M. Abdussamad., K. P. Said Koya., K. K. Joshi., S. Kemparaju., D. Prakasan, M. N. K. Elayathu \& Manju Sebastine. 2013. Biology and fishery of the bullet tuna, Auxis rochei (Risso, 1810) in Indian waters. Indian J. Fish., 60 (2) : 13-20.

Kahraman, E. A., Göktürk, D., dan Karakulak, F. S. 2011. Age and growth of bullet tuna, auxis rochei (risso), from Turkish Mediterranean coasts. African J. Biotech., 10(15): 3009-3013.

Macias D, L. Lema, M.J. Gòmez Vives, J.M. Ortiz de Urbina, J.M. De la Serna (2006). Some biological aspects of small tunas (Euthynnus alletteratus, Sarda sarda and Auxis rochei) from the south western Spanish Mediterranean. ICCAT, Coll. Vol. Sci. Pap. 59(2): 579589.

Noegroho. T, T. Hidayat, K. Amri. 2013. Some biological aspects of frigate tuna (Auxis thazard), bullet tuna (Auxis rochei), and kawakawa (Euthynnus affinis) in west coasts Sumatera IFMA 572, eastern Indian Ocean. IOTC Third Working Party on Neritic Tuna. Bali, Indonesia (19): 1-13.

Pauly, D. 1980. On the interrelationships between natural mortality, growth parameters and mean environmental temperature in 175 fish stocks. Journal du Conseil International pour I' Exploration de la Mer, 39:175192.

Pauly, D. 1983. Some simple methods in tropical fish stock assessment. FAO Fisheries Technical Paper. Abb. Rome. (234): 52p. 
Pauly D., and Munro J. 1984. Once more on the comparison of growth in fish and invertebrates, Fishbyte. (2): 21.

Pillai, P.P dan N. G. K. Pillai. 2000. Tuna fisheries of India. dalam Pillai \& Menon. Ed. 2000. Marine fisheries research and management. central marine fisheries research institute. Kerala, India: 405-425.

Plandri, G, L. Lanteri, F. Garibaldi, L. Orsi Relini, 2009. Biological parameters of bullet tuna in the Ligurian Sea. Collect. Vol. Sci. Pap. ICCAT, 64(7): 2272-2279.

Rohit, P., E.M. Abdussamad, K.P. Said Koya, M. Sivadas $\&$ Subhadeep Gosh. 2011. Tuna fishery of india with special reference to biology and population characteristics of neritic tunas exploited from Indian EEZ. IOTC First Working Party on Neritic Tuna. (10):111.

Anonymous, 2013. Statistik perikanan tangkap Indonesia 2013. Direktorat Jenderal Perikanan Tangkap. Kementerian Kelautan dan Perikanan. Jakarta.
Setyadi, B., D. Novianto, A. Bahtiar. 2013. Size structure of bullet tuna (Auxis rochei, Risso, 1810) caught by small scale and industrial purse seine fisheries in indian ocean -south of java based on trial scientific observer data. IOTC Third Working Party on Neritic Tuna (30): $1-10$.

Uchida, R. N. 1981. Synopsis of biological data on frigate tuna, Auxis thazard, and bullet tuna, Auxis rochei. FAO Fish. Synop. 124p.

Valeiras, X., Macias, D., Gomez, M. .J., Lema, L., GarciaBarcelona, S., De Urbinqa Ortiz, J. M. \& J. M. De la Serna,. 2008. Age and growth of bullet tuna (Auxis rochei) in the western Mediterranean Sea. Collect. Vol. Sci. Pap. ICCAT. 62 (5): 1.629-1.637.

Widodo. A. A, F. Satria, L. Sadiyah dan J. Riyanto. 2011. Neritic tuna species caught drifting gillnet in indian ocean based in Cilacap Indonesia. IOTC-First Working Party on Neritic Tuna. (21):1-19. 